\title{
GNAO1 wt Allele
}

National Cancer Institute

\section{Source}

National Cancer Institute. GNAO1 wt Allele. NCI Thesaurus. Code C114349.

Human GNAO1 wild-type allele is located in the vicinity of $16 q 13$ and is approximately 166

$\mathrm{kb}$ in length. This allele, which encodes guanine nucleotide-binding protein $\mathrm{G}(\mathrm{o})$ subunit alpha protein, plays a role in the mediation of $\mathrm{G}$ protein-dependent signaling. 